\title{
RESEARCH
}

Open Access

\section{Effects of three coniferous plantation species on plant-soil feedbacks and soil physical and chemical properties in semi- arid mountain ecosystems}

Chun Han ${ }^{1,2}$, Yongjing Liu ${ }^{1,2}$, Cankun Zhang ${ }^{1,2}$, Yage Li ${ }^{1,2}$, Tairan Zhou ${ }^{1,2}$, Salman Khan ${ }^{1,2}$, Ning Chen ${ }^{1,2}$ and Changming Zhao ${ }^{1,2^{*}}$

\begin{abstract}
Background: Large-scale afforestation can significantly change the ground cover and soil physicochemical properties, especially the soil fertility maintenance and water conservation functions of artificial forests, which are very important in semi-arid mountain ecosystems. However, how different tree species affect soil nutrients and soil physicochemical properties after afforestation, and which is the best plantation species for improving soil fertility and water conservation functions remain largely unknown.

Methods: This study investigated the soil nutrient contents of three different plantations (Larix principis-rupprechtii, Picea crassifolia, Pinus tabuliformis), soils and plant-soil feedbacks, as well as the interactions between soil physicochemical properties.

Results: The results revealed that the leaves and litter layers strongly influenced soil nutrient availability through biogeochemical processes: P. tabuliformis had higher organic carbon, ratio of organic carbon to total nitrogen (C:N) and organic carbon to total phosphorus (C:P) in the leaves and litter layers than L. principis-rupprechtii or $P$. crassifolia, suggesting that higher C:N and C:P hindered litter decomposition. As a result, the L. principis-rupprechtii and $P$. crassifolia plantation forests significantly improved soil nutrients and clay components, compared with the $P$. tabuliformis plantation forest. Furthermore, the L. principis-rupprechtii and P. crassifolia plantation forests significantly improved the soil capacity, soil total porosity, and capillary porosity, decreased soil bulk density, and enhanced water storage capacity, compared with the P. tabuliformis plantation forest. The results of this study showed that, the strong link between plants and soil was tightly coupled to C:N and C:P, and there was a close correlation between soil particle size distribution and soil physicochemical properties.
\end{abstract}

Conclusions: Therefore, our results recommend planting the L. principis-rupprechtii and P. crassifolia as the preferred tree species to enhance the soil fertility and water conservation functions, especially in semi-arid regions mountain forest ecosystems.

Keywords: Plantation, C:N:P stoichiometry, Plant-soil feedbacks, Soil physicochemical properties, Mountain ecosystems

\footnotetext{
* Correspondence: zhaochm@|zu.edu.cn

'State Key Laboratory of Grassland and Agro-Ecosystems, School of Life Sciences, Lanzhou University, 730000 Lanzhou, China

${ }^{2}$ Gansu Provincial Field Scientific Observation and Research Station of Mountain Ecosystems, 730000 Lanzhou, China
}

(C) The Author(s). 2021 Open Access This article is licensed under a Creative Commons Attribution 4.0 International License, which permits use, sharing, adaptation, distribution and reproduction in any medium or format, as long as you give appropriate credit to the original author(s) and the source, provide a link to the Creative Commons licence, and indicate if changes were made. The images or other third party material in this article are included in the article's Creative Commons licence, unless indicated otherwise in a credit line to the material. If material is not included in the article's Creative Commons licence and your intended use is not permitted by statutory regulation or exceeds the permitted use, you will need to obtain permission directly from the copyright holder. To view a copy of this licence, visit http://creativecommons.org/licenses/by/4.0/. 


\section{Introduction}

The reforestation remains one of the most effective strategies for coping with climate change (Jean-Francois et al. 2019), which is also the most effective management method to solve the problems of soil erosion all over the world (Clemente et al. 2004; Kou et al. 2016). It is considered to be an effective strategy to prevent soil erosion and degradation and to promote the restoration of degraded ecosystems (Zhang et al. 2011). For the past three decades, to prevent soil erosion and desertification and improve water conservation capacity, the Grain to Green Program (GTGP) has been implemented by the Chinese government (Chang et al. 2012). Large-scale afforestation increased ground cover and caused changes in soil physical and chemical properties (Fu et al. 2010). Forests as ecosystem engineers not only have species-specific effects on soil physicochemical properties and soil communities (soil animal communities and soil microbial communities) (Vesterdal et al. 2008; Prescott and Grayston 2013), but also regulate climate, mineral cycling and prevent soil erosion (Kozlowski 2002). Besides, artificial forests could potentially lead to circulation and feedback effects of mineral nutrients between above-ground and below-ground ecosystems (Wang et al. 2009; Peichl et al. 2012). Therefore, the study of vegetation restoration processes and their impacts on nutrient cycling and soil properties will provide an important guide to forest management aimed at improving the ecological restoration of natural and artificial forests, especially in semiarid mountain ecosystem regions.

It is well known that vegetation is an important factor affecting soil physical and chemical properties. Leaves of different tree species have generated species-specific effects on litter layer decomposition and nutrients released into the soil (Norris et al. 2012; Aponte et al. 2013). Tree species affect soil nutrient mineralization and availability through soil microorganisms, thus affecting soil fertility (Aponte et al. 2013; Huang et al. 2013). Previous studies have shown that environmental factors influence leaves and then affect many service functions of the ecosystems (Ayres et al. 2009; Aponte et al. 2013). Thus, leaf quality largely determines the decomposition of litter, as well as the release of nutrients and minerals into the soil (Norris et al. 2012; Aponte et al. 2013), indicating the relationship among leaves, litter, and soil (Lucas-Borja et al. 2018). However, the studies about the effects of leaves and litter from different tree species on soil organic carbon, nitrogen cycling, and water conservation functions in semi-arid mountain forest ecosystems are still lacking.

Soil plays an important fertility and stability function in forest ecosystems (Lucas-Borja et al. 2018), and it directly or indirectly regulates and influences many biological processes (Zhang et al. 2018). Soil properties are determined by chemical, physical and biological processes, which play a key role in determining plant growth, community composition, and individual productivity (van der Putten et al. 2013). Besides, different plant species tend to have species-specific effects on soil quality and quantity (Hobbie et al. 2006; Ayres et al. 2009), and they also change the physical, chemical, and biological properties of soil (Qiao et al. 2019). Thus, aboveground and belowground processes of forest ecosystems determine plant-soil feedbacks and influence the composition of the plant community and nutrient cycling processes (Kardol et al. 2006; van der Putten et al. 2013), potentially affecting ecosystem functioning, such as interactions between plants and other communities (van der Putten et al. 2013), conserving water resource and preventing soil losses. Therefore, understanding the relationships between plantation types and soil physicochemical properties is of great significance for the soil and water conservation, nutrient cycling, and soil health assessment of forest stands.

Soil particle-size distribution (PSD) refers to the percentage of each particle size class in the soil, which can reflect the influence of soil water movement, solute transport, nutrient status, and vegetation types on soil texture (Sun et al. 2016). Soil texture is divided into clay, silt, and sand, which is one of the important physical parameters of soil ( $\mathrm{Hu}$ et al. 2011; Mohammadi and Meskini-Vishikaee 2013; Xu et al. 2013). The change of soil particle-size distribution is the result of the combined effects of soil evolution, vegetation restoration, and environmental factors. Soil texture and organic matter are the key factors affecting soil particle size (Qi et al. 2018). Previous studies have shown that the aboveground part of plants can effectively increase the roughness of the surface, thus increasing the content of fine particles and nutrients in the soil, leading to the change of soil structure (Xiang et al. 2015). However, the relationship between soil physicochemical properties and soil particle-size distribution and their effects on water conservation functions are scarce.

Xinglong Mountain is an important water conservation area on semi-arid land in northwestern China. Since the implementation of China's Three-North Shelterbelt forest program in the 1980s, a large-scale artificial afforestation project has been carried out in Xinglong mountain, and the planted forest species were Larix principisrupprechtii, Picea crassifolia, Pinus tabuliformis. Although artificial afforestation has been carried out for many years, there is no systematic evaluation of the soil and water conservation capacity and ecological construction benefits of the plantations. In this study, we hypothesize that there is a strong feedback effect of nutrients between plants and soil. Tree species may influence the soil organic carbon (SOC), total nitrogen (TN), and total phosphorus (TP) of different afforestation and 
then will affect the soil physicochemical properties, structure, and texture. This study aimed to: (1) investigate the influence of three different tree species on the nutrient status of plants and soil and plant-soil feedbacks; (2) analyse the effects of three different tree species on soil physical and chemical properties; and (3) explore the impacts of soil physical and chemical properties of three different forest stands on soil particle-size distribution characteristics and their influence factors. Therefore, the results of this study can provide theoretical guidance in the selection of forest species for afforestation and forest management, particularly in the semi-arid mountain forest ecosystems.

\section{Materials and Methods}

\section{Study site description}

The research area is located in the Gansu Xinglongshan National Nature Reserve (35 $44^{\prime} 20.12^{\prime \prime}$ N, 104 ${ }^{\circ} 1^{\prime} 3.07^{\prime \prime}$ E, $2778 \mathrm{~m}$ a.s.l.), in the Loess Plateau, China (Fig. 1). As a "green rock island" in the Loess Plateau, it is an important water conservation forest and biodiversity protection area in the upper reaches of the Yellow River.
The climate in this region is classified as semi-arid continental monsoon climate, and the annual precipitation is about $450-622 \mathrm{~mm}$. The precipitation frequency is not uniform, mostly concentrated in July to September. The effective accumulated temperature was 1800$2800{ }^{\circ} \mathrm{C}$, and the average annual relative air humidity was $68 \%$.

We selected three study sites with different dominant tree species planted 30 years ago, the planting distance is about $4 \mathrm{~m} \times 4 \mathrm{~m}$, and all the plantations are in semisunny slope. The distance between each study site is less than $10 \mathrm{~km}$, and the environmental, meteorological, soil and the parent material among stands were homogeneous. More basic information of the three plantation stands was summarized in Table 1 . The type of lands before plantations is a natural succession of grassland, no human disturbance and management to the forests and soils since the plantation. During the growth and succession of different tree species, the soil physicochemical properties changed accordingly, thus potentially affecting ecosystem functioning. Therefore, these differences

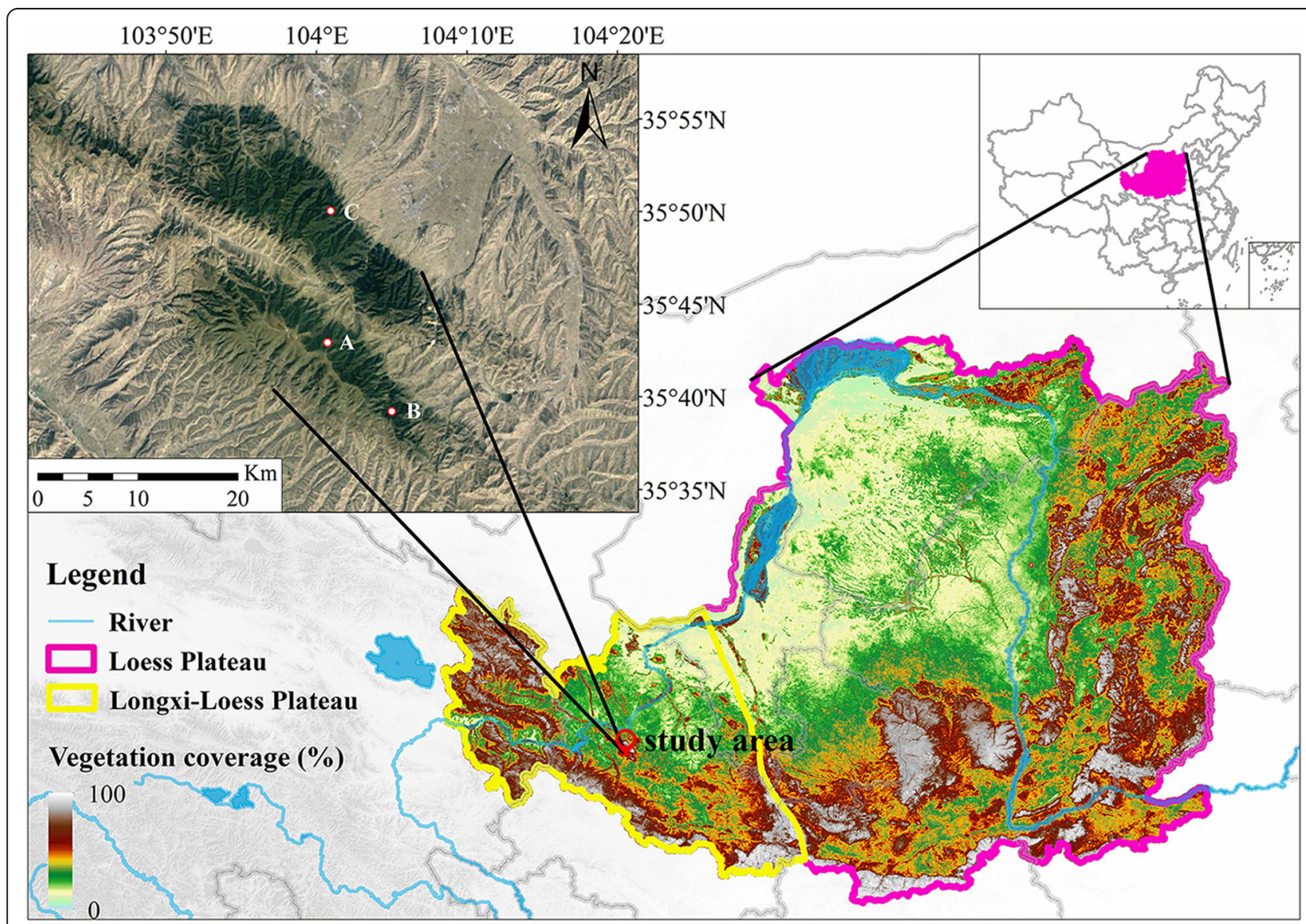

Fig. 1 The location map of Xinglong Mountain in the Loess Plateau of China and sample plot information (A: L. principis-rupprechtii forest, B: P. crassifolia forest, C: P. tabuliformis forest) 
Table 1 The basic information of traits of the three plantation stands

\begin{tabular}{|c|c|c|c|c|c|}
\hline Forest stands & Stand density (trees $\cdot \mathrm{ha}^{-1}$ ) & Average DBH $(\mathrm{cm})$ & Average height $(\mathrm{m})$ & LAI & Slope \\
\hline L. principis-rupprechtii & 608 & 26.19 & 16.43 & 3.49 & $5^{\circ}$ \\
\hline P. crassifolia & 560 & 26.04 & 12.97 & 4.17 & $4.5^{\circ}$ \\
\hline P. tabuliformis & 592 & 23.69 & 12.10 & 2.68 & $8^{\circ}$ \\
\hline
\end{tabular}

among stands can be attributed to tree species. There were a large amount of herbaceous vegetation (i.e., Carex rigescens, Fragaria orientalis, Aconitum sinomontanum and Potentilla bifurca) and shrubs (i.e., Sorbus koeheana, Berberis kansuensis, Rosa sweginzowii, Cotoneaster multiflorus, Spiraea alpine and Lonicera hispida) growing on the forest floor and the litter thickness was about $10 \mathrm{~cm}$.

\section{Analysis methods of nutrient contents in the leaves and litter layers}

Three sample plots $(25 \mathrm{~m} \times 25 \mathrm{~m})$ in each forest stand were randomly selected, and two trees or points were selected randomly in each sample plot to collect leaves (i.e., needles), soil, and litter samples. There are six replicates for leaves, soil, or litter samples in each forest stand. The leaf samples were randomly collected from each of the three different forest stand sites in August 2018, and litter samples were sampled under the canopy of each selected tree (The distance between each sampling tree or point is greater than $10 \mathrm{~m}$. The collected litter is mainly fallen needles of trees). Leaves and litter samples were processed in a grinder (dried to constant weight at $75{ }^{\circ} \mathrm{C}$ ) and sieved through a 60-mesh sieve. Organic carbon values of the leaf and litter layer were determined using the $\mathrm{K}_{2} \mathrm{Cr}_{2} \mathrm{O}_{7}-\mathrm{H}_{2} \mathrm{SO}_{4}$ oxidation method (Bao 2000; Wang 2009), the total nitrogen (TN) values were determined using the micro-Kjeldahl method (Bao 2000; Zhang et al. 2019a), whilst total phosphorus (TP) values of leaf and litter layer were determined colorimetrically (ammonium molybdate method) after wet digestion with $\mathrm{H}_{2} \mathrm{O}_{2}-\mathrm{H}_{2} \mathrm{SO}_{4}$, and the total potassium (TK) values were determined using an atomic absorption spectrophotometer (detection limit is $0-1000 \mathrm{mg} \cdot \mathrm{L}^{-1}$ ) (Aurora, AI-1200, Canada) after wet digestion with $\mathrm{H}_{2} \mathrm{O}_{2}-\mathrm{H}_{2} \mathrm{SO}_{4}$ (Bao 2000; Zhang et al. 2019a).

\section{Analysis methods of soil physical and chemical properties} To determine soil nutrient contents, the soil samples were collected from the $0-10,10-20$ and $20-30 \mathrm{~cm}$ soil layers at each site. We randomly selected two pionts in each sample plot $(25 \mathrm{~m} \times 25 \mathrm{~m})$. For each forest stand, 18 soil samples, 6 leaf samples, and 6 litter samples were collected. Totally, 48 soil samples, 18 leaf samples, and 18 litter samples were collected. Air-dried soil samples screened by 2 - and $0.15-\mathrm{mm}$ mesh sieve were used to determine soil physiochemical properties and particlesize distribution (PSD). Soil organic carbon (SOC) content were determined using the $\mathrm{K}_{2} \mathrm{Cr}_{2} \mathrm{O}_{7}-\mathrm{H}_{2} \mathrm{SO}_{4}$ oxidation method (Bao 2000; Wang 2009). Soil total nitrogen (TN) values were determined using the micro-Kjeldahl method (Yang et al. 2018), whilst soil total phosphorus (TP) and total potassium (TK) values were determined colorimetrically (ammonium molybdate method) and flame photometer after wet digestion with $\mathrm{HClO}_{4}$ $\mathrm{H}_{2} \mathrm{SO}_{4}$ (Bao 2000; Cao and Chen 2017), respectively. Inorganic nitrogen in the form of nitrate nitrogen $\left(\mathrm{NO}_{3}^{-}-\mathrm{N}\right)$ and ammonium nitrogen $\left(\mathrm{NH}_{4}^{+}-\mathrm{N}\right)$ were determined through colorimetry (Bao 2000), and available phosphorus (AP) was extracted with $0.5 \mathrm{~mol} \cdot \mathrm{L}^{-1}$ $\mathrm{NaHCO}_{3}$, then determined by molybdenum-antimony colorimetry (Bao 2000; Kou et al. 2016). Available potassium (AK) was extracted with $1 \mathrm{~mol} \cdot \mathrm{L}^{-1} \mathrm{CH}_{3} \mathrm{COONH}_{4}$ then determined by flame photometry (Bao 2000; Zhou et al. 2015). TN, TP, $\mathrm{NO}_{3}^{-}-\mathrm{N}$ and $\mathrm{NH}_{4}^{+}-\mathrm{N}$ were measured using an automatic intermittent chemical analyzer (SmartChem140, France). The AK and TK in the soil were determined using flame atomic absorption spectrophotometric method (detection limit is $0-1000 \mathrm{mg} \cdot \mathrm{L}^{-1}$ ) (Aurora, AI-1200, Canada).

To determine soil physical properties, undisturbed samples were obtained from the $0-10,10-20$ and 20$30 \mathrm{~cm}$ soil layers using a ring knife at each typically repeated plots for three different forest stands (six intact soil cores were obtained from each of the three soil layers for each forest stand). The bulk density and soil capacity of the soil samples were measured using the method exposed by Zhang et al. (2019b). The total porosity was determined by measuring soil moisture content at saturation (total volume of water-filled soil pores) and capillary porosity (capillary porosity is the percentage of soil voids in soil volume) was determined with the method exposed by Qiu et al. (2019).

\section{Determination of the soil particle-size distribution of the soil samples}

The soil particle-size distribution was measured using a laser particle analyzer (Mastersizer 2000, Malvern Company, UK), each $0.25 \mathrm{~g}$ soil sample was pretreated with $10 \% \mathrm{H}_{2} \mathrm{O}_{2}$ solution to remove organic matter, and $10 \%$ $\mathrm{HCl}$ solution was added to remove carbonate salts. Add deionized water to soak for $12 \mathrm{~h}$, then the liquid 
supernatant was removed. The samples were chemically dispersed with $0.06 \mathrm{~mol} \cdot \mathrm{L}^{-1}$ sodium hexametaphosphate and were mechanically dispersed in an ultrasonic bath for $10 \mathrm{~min}$ (Qi et al. 2018). The measurements were repeated three times for each sample, and the soil particlesize distribution (PSD) was classified into clay $(<2 \mu \mathrm{m})$, silt $(2-50 \mu \mathrm{m})$, and sand $(50-2000 \mu \mathrm{m})$ according to United States Department of Agriculture classification (USDA) classification system (Xia et al. 2020; Zhai et al. 2020).

\section{Statistical analyses}

The effects of different forest species on the physical and chemical properties of the soil, nutrient contents in the vegetation and litter layers, and soil particle-size distribution (PSD) were evaluated using one-way ANOVA (the normal distribution and homogeneity of variance of the data had been checked), followed by least significant difference (LSD) tests for different soil layer $(P<0.05)$. Pearson correlation analysis was undertaken to identify the relationships between SOC, TN, TP, TK, bulk density, soil capacity, total porosity, and capillary porosity. The relationship between soil physicochemical properties and soil particle-size distribution was analyzed by confirmatory factor analysis using the maximum likelihood method to build a path model. All statistical analyses were performed using SPSS 26.0 and AMOS 24.0 (SPSS Inc. an IBM Company, Chicago, IL, USA), and all figures were prepared with Origin 2020 software (Origin Lab Inc., Northampton, MA, USA).

\section{Results}

Nutrient contents of the leaves and litter layers for the three plantations

The content of organic carbon (OC), TN, TP, TK, and $\mathrm{C}: \mathrm{N}: \mathrm{P}$ stoichiometry were different in leaves and litter layers for different tree species (Fig. 2). The organic carbon content in the leaves and litter of $P$. tabuliformis was significantly higher than that of $L$. principis-rupprechtii (14\% and $2 \%$ more, respectively) and $P$. crassifolia (16\% and $3 \%$ more, respectively) (Fig. 2a). However, the content of N, P, and $\mathrm{K}$ in the leaves and litter of $P$. tabuliformis was lower than that of L. principis-rupprechtii ( $\mathrm{N}: 36 \%$ and $44 \%$ less, P: $43 \%$ and $45 \%$ less, $\mathrm{K}: 37 \%$ and $34 \%$ less, respectively) and P. crassifolia (N: $46 \%$ and $25 \%$ less, P: $65 \%$ and $30 \%$ less, K: $24 \%$ and $21 \%$ less, respectively) (Fig. $2 \mathrm{~b}-2 \mathrm{~d}$ ). The $\mathrm{C}: \mathrm{N}$ ratio, $\mathrm{C}: \mathrm{P}$ ratio and $\mathrm{N}: \mathrm{P}$ ratio of leaves of $P$. tabuliformis were markedly higher than that of L. principis-rupprechtii, but these ratios

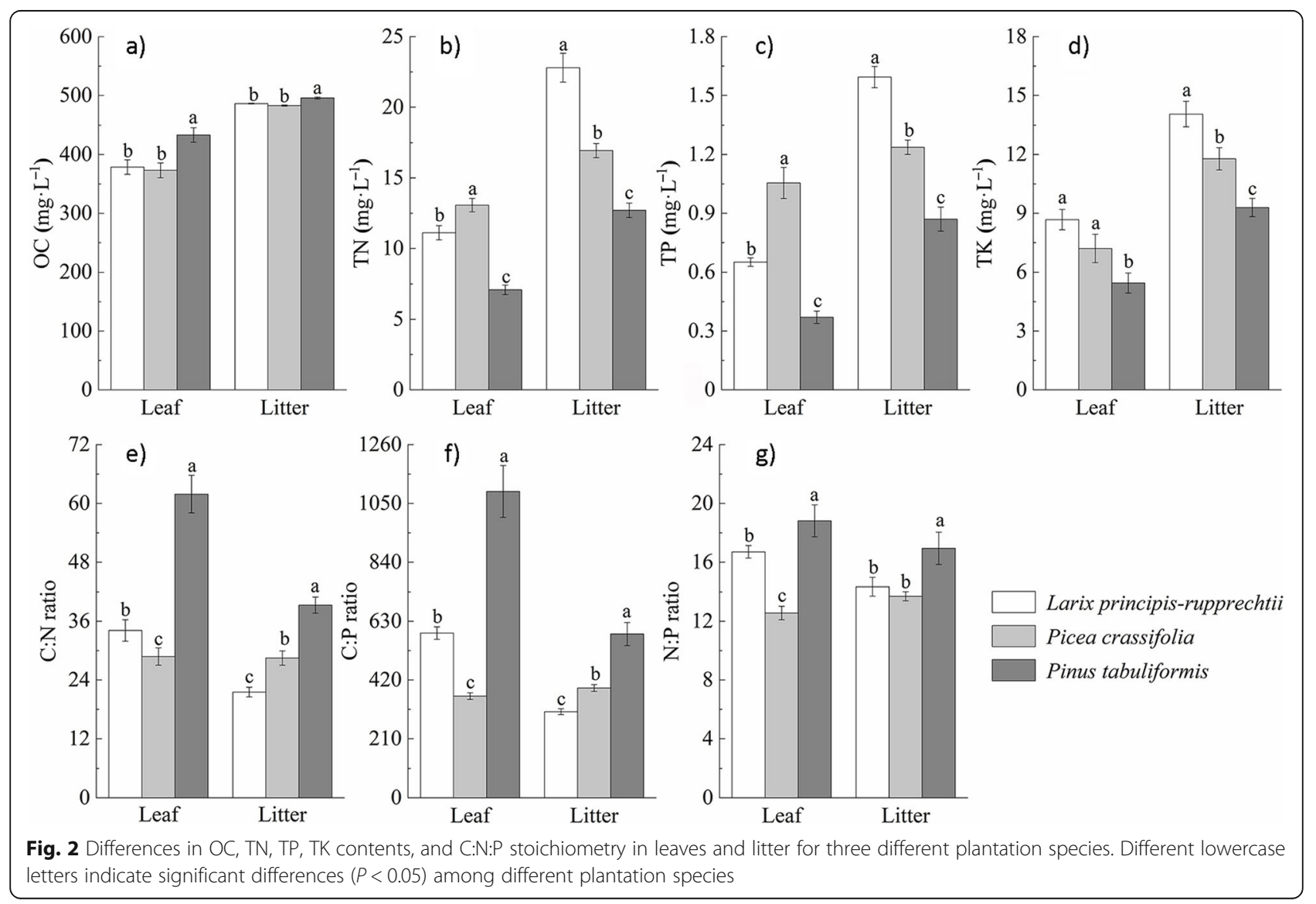


of $P$. crassifolia were significantly lower than those of $L$. principis-rupprechtii (Fig. 2e-2 g). The C:N ratio and C:P ratio of the litter of $P$. tabuliformis were the highest, and were significantly higher in $P$. crassifolia than in L. principisrupprechtii (Fig. 2e-2f). The N:P ratio of the litter of $P$. tabuliformis was higher than that of $L$. principis-rupprechtii and $P$. crassifolia, and there was no statistic difference between $L$. principis-rupprechtii and P. crassifolia (Fig. 2g).

\section{Soil nutrient contents for the three plantation stands}

Overall, SOC, TN, and TP showed a gradually decreasing trend from the litter layer to deep soil layers for the three plantation stands (Fig. 3). The only exception was for the TP in the L. principisrupprechtii stand, where there were no significant differences between different soil layers (Fig. 3a-3c). However, there was no significant difference in soil TK in the different soil layers for the three plantation species (Fig. 3d). Furthermore, the C:N ratio, C:
$\mathrm{P}$ ratio, and $\mathrm{N}: \mathrm{P}$ ratio exhibited a gradually decreasing trend from surface soil layers to deep soil layers; the exceptions were the $\mathrm{C}: \mathrm{N}$ ratio of the $P$. crassifolia stand and the C:P ratio and N:P ratio of the $P$. tabuliformis stand, where there was no significant difference between the different soil layers (Fig. $3 \mathrm{e}^{-}$ $3 \mathrm{~g})$. On the whole, the SOC, TN, TP, C:N ratio, C: $\mathrm{P}$ ratio and $\mathrm{N}: \mathrm{P}$ ratio of the $L$. principis-rupprechtii stand were higher than those of the $P$. crassifolia and $P$. tabuliformis stands; except for individual nutrient indexes (such as TN and N:P ratio), for which there was no significant difference between the surface and the deep soil layers.

Available nutrients $\left(\mathrm{NH}_{4}^{+}-\mathrm{N}, \mathrm{NO}_{3}^{-}-\mathrm{N}, \mathrm{AP}\right.$, and $\left.\mathrm{AK}\right)$ in the soil also exhibited a gradually decreasing trend from the topsoil to deep soil layers for the three forest stands (Fig. 4). At the same depth, the available nutrients were highest in the $L$. principis-rupprechtii stand, followed by the P. crassifolia stand, and were lowest in the P. tabuliformis stand (Fig. 4). The differences declined with depth in the soil profile for

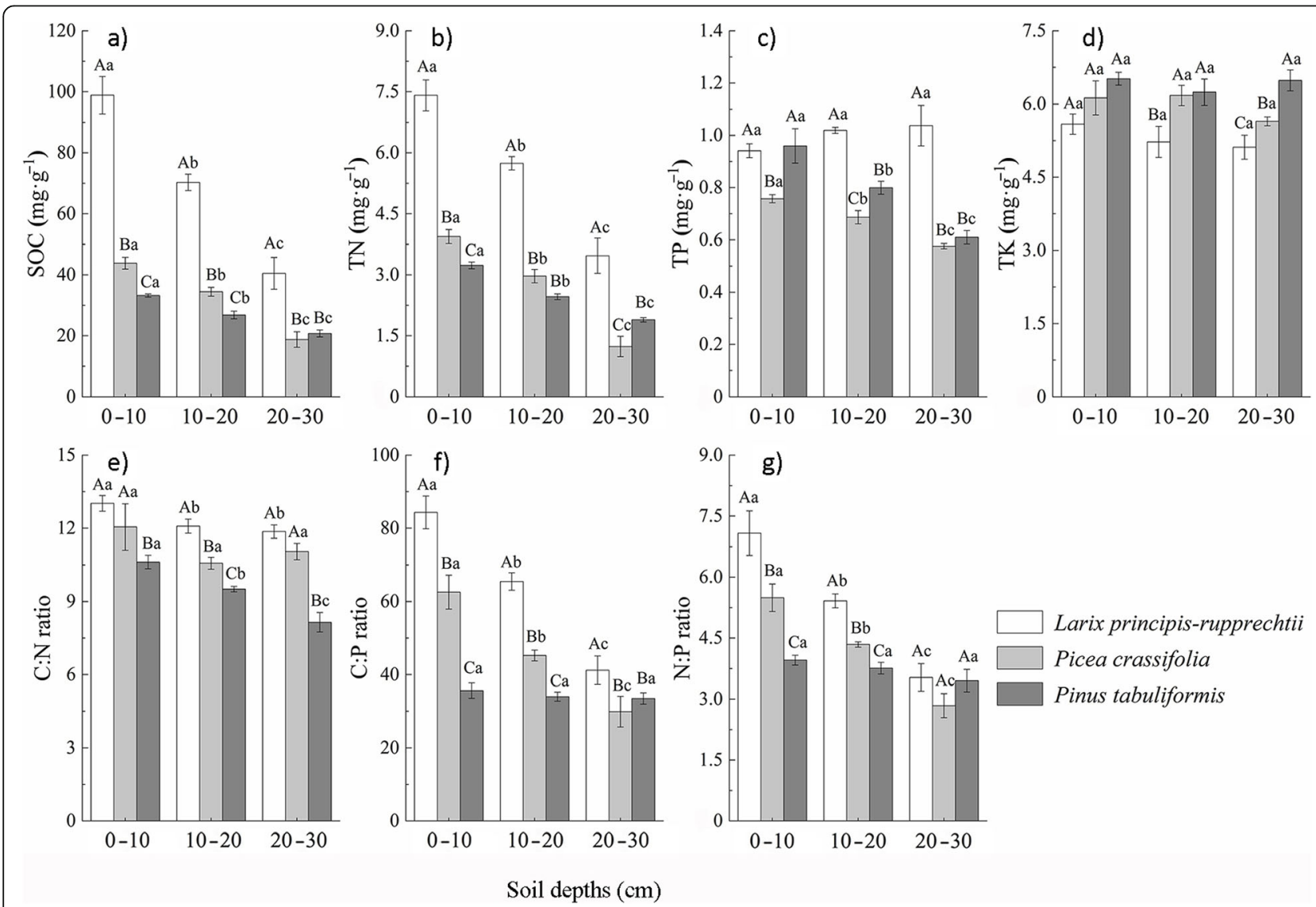

Fig. 3 SOC, TN, TP, TK, C:N ratio, C:P ratio, and N:P ratio in $10 \mathrm{~cm}$ soil layers to a depth of $30 \mathrm{~cm}$ under three different plantation species. Different capital letters within the same depth indicate significant difference $(P<0.05)$ among three different plantation species. Different lowercase letters for the same study site indicate significant differences $(P<0.05)$ between different soil layers. The same is the case below 


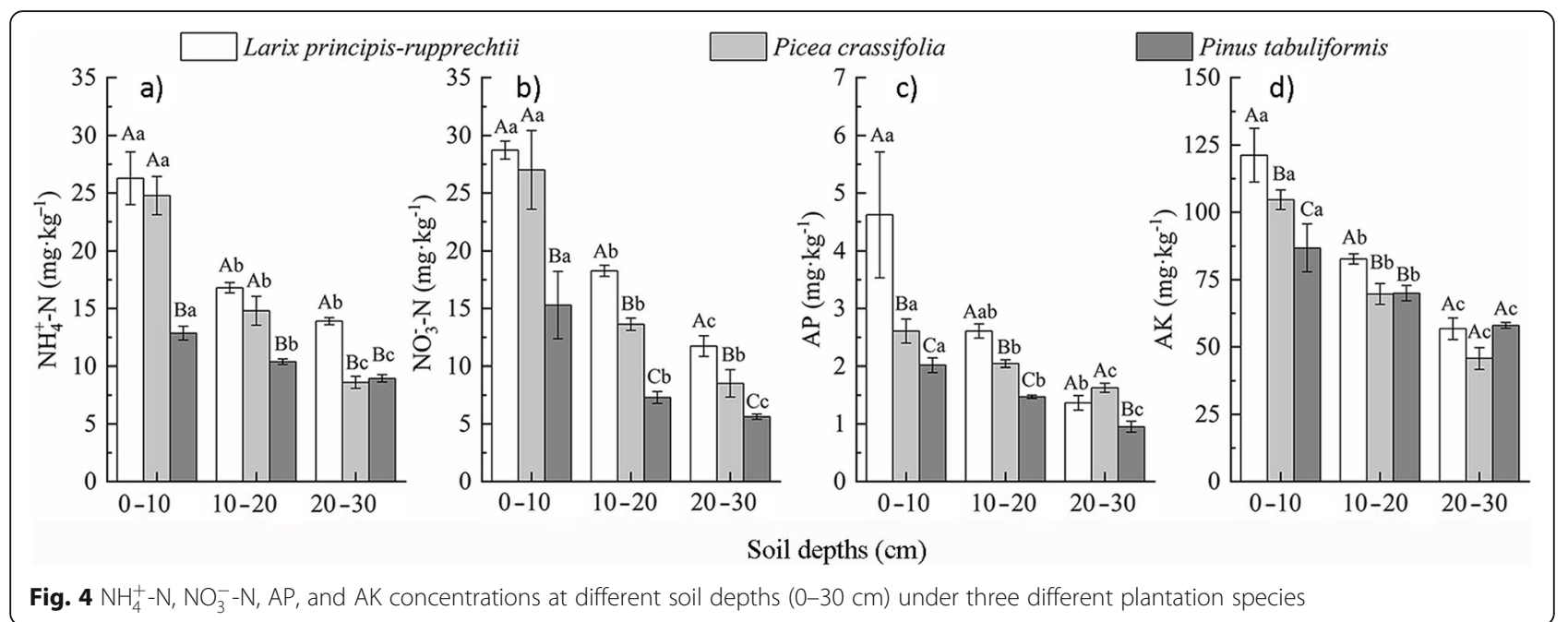

the three forest stands, so there was no significant difference in AP and AK in the deepest layer.

\section{Soil physical properties for the three plantation stands}

The different tree species also had different effects on the soil physical properties of the different soil layers (Fig. 5). There was no significant difference in soil bulk density, soil capacity, soil total porosity, and soil capillary porosity in soil layers down to $30 \mathrm{~cm}$ under the $P$. tabuliformis stand (Fig. 5a-d). The soil capacity, soil total porosity, and soil capillary porosity exhibited a gradually decreasing trend from the topsoil to deep soil layers under $L$. principis-rupprechtii and $P$. crassifolia stands, while soil bulk density showed the opposite trend. The soil bulk density of $P$. crassifolia $\left(0.92-1.26 \mathrm{~g} \cdot \mathrm{cm}^{-1}\right)$ and $P$. tabuliformis stands $\left(1.15-1.16 \mathrm{~g} \cdot \mathrm{cm}^{-1}\right)$ was higher than that of $L$. principis-rupprechtii $\left(0.76-0.94 \quad \mathrm{~g} \cdot \mathrm{cm}^{-1}\right)$ (Fig. 5a), while the soil capacity, soil total porosity, and soil capillary porosity of the $L$. principis-rupprechtii stand were higher than those of the $P$. crassifolia and $P$. tabuliformis stands (Fig. 5b-d), except that there was no significant difference in the soil capillary porosity in the $20-30 \mathrm{~cm}$ layer (Fig. $5 \mathrm{~d}$ ).

\section{The correlation between soil nutrient contents and physical properties}

Pearson correlation analysis was performed to evaluate the correlation between soil nutrient contents and physical properties (Table 2). The results revealed that the $\mathrm{SOC}, \mathrm{TN}, \mathrm{NH}_{4}^{+}-\mathrm{N}, \mathrm{NO}_{3}^{-}-\mathrm{N}, \mathrm{AP}$, and $\mathrm{AK}$ in the soil were significantly positively correlated with soil capacity, total porosity, and capillary porosity $(P<0.05$ or $P<0.01)$, but there were no significant correlations between soil total

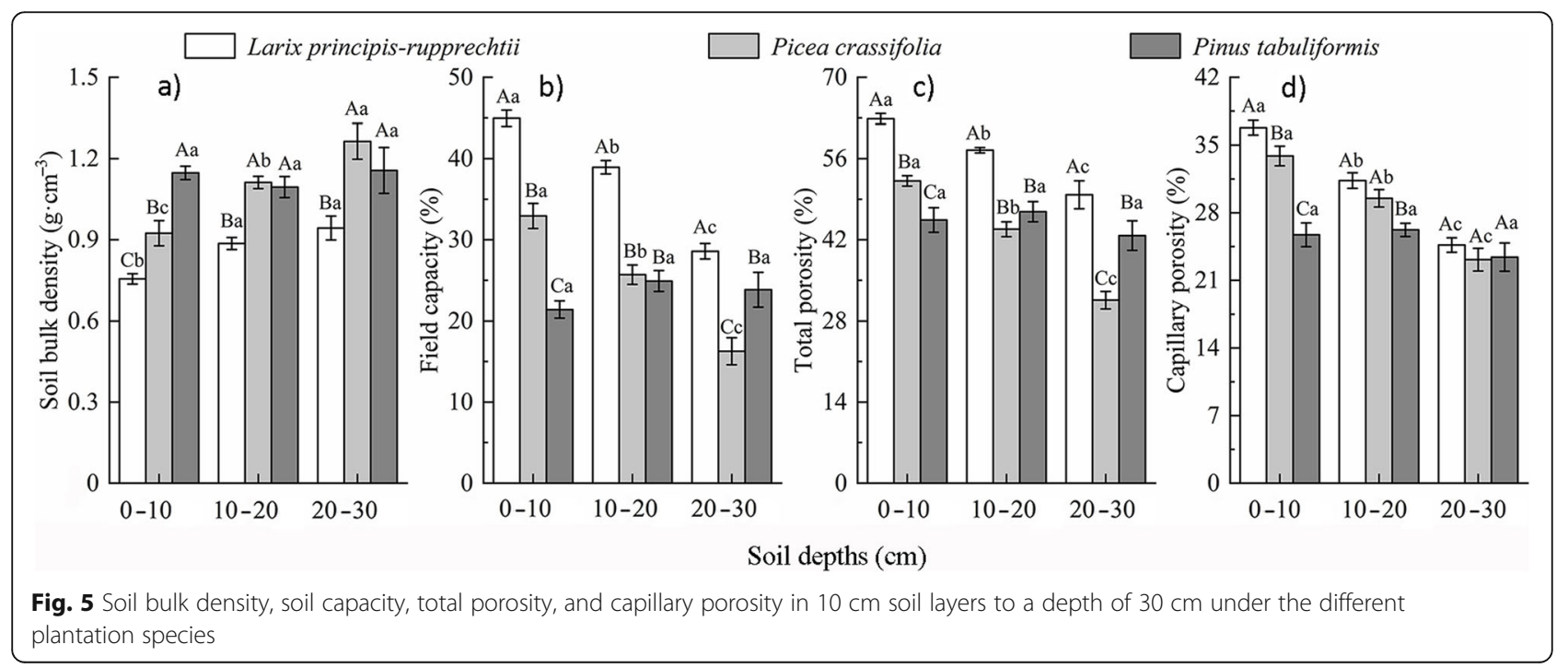


Table 2 Pearson correlation coefficients between soil nutrient contents and physical properties

\begin{tabular}{|c|c|c|c|c|c|c|c|c|c|c|c|}
\hline & SOC & TN & TP & TK & $\mathrm{NH}_{4}^{+}-\mathrm{N}$ & $\mathrm{NO}_{3}^{-}-\mathrm{N}$ & AP & AK & $\begin{array}{l}\text { Soil bulk } \\
\text { density }\end{array}$ & $\begin{array}{l}\text { Soil } \\
\text { capacity }\end{array}$ & $\begin{array}{l}\text { Total } \\
\text { porosity }\end{array}$ \\
\hline$\overline{T N}$ & $0.98^{* *}$ & & & & & & & & & & \\
\hline TP & 0.34 & 0.45 & & & & & & & & & \\
\hline TK & -0.50 & -0.44 & -0.24 & & & & & & & & \\
\hline $\mathrm{NH}_{4}^{+}-\mathrm{N}$ & $0.81^{* *}$ & $0.81^{* *}$ & 0.18 & -0.24 & & & & & & & \\
\hline $\mathrm{NO}_{3}^{-}-\mathrm{N}$ & $0.72^{*}$ & $0.73^{*}$ & 0.28 & -0.20 & $0.95^{* *}$ & & & & & & \\
\hline$A P$ & $0.92^{* *}$ & $0.88^{* *}$ & 0.17 & -0.28 & $0.87^{* *}$ & $0.81^{* *}$ & & & & & \\
\hline AK & $0.79^{*}$ & $0.83^{* *}$ & 0.30 & 0.03 & $0.91^{* *}$ & $0.88^{* *}$ & $0.88^{* *}$ & & & & \\
\hline Soil bulk density & $-0.88^{* *}$ & $-0.91^{* *}$ & -0.31 & 0.47 & $-0.82^{* *}$ & $-0.69^{*}$ & $-0.71^{*}$ & $-0.73^{*}$ & & & \\
\hline Soil capacity & $0.95^{* *}$ & $0.96^{* *}$ & 0.27 & -0.46 & $0.84^{* *}$ & $0.73^{*}$ & $0.82^{* *}$ & $0.78^{*}$ & $-0.97^{* *}$ & & \\
\hline Total porosity & $0.80^{* *}$ & $0.87^{* *}$ & 0.29 & -0.25 & $0.69^{*}$ & 0.55 & 0.61 & $0.70^{*}$ & $-0.95^{* *}$ & $0.92^{* *}$ & \\
\hline $\begin{array}{l}\text { Capillary } \\
\text { porosity }\end{array}$ & $0.85^{* *}$ & $0.84^{* *}$ & 0.11 & -0.20 & $0.95^{* *}$ & $0.90^{* *}$ & $0.91^{* *}$ & $0.91^{* *}$ & $-0.79^{*}$ & $0.87^{* *}$ & $0.71^{*}$ \\
\hline
\end{tabular}

porosity and $\mathrm{NO}_{3}^{-}-\mathrm{N}, \mathrm{TP}$, and TK. However, there were significant negative correlations between soil bulk density and $\mathrm{SOC}, \mathrm{TN}, \mathrm{NH}_{4}^{+}-\mathrm{N}, \mathrm{NO}_{3}^{-}-\mathrm{N}, \mathrm{AP}$, and $\mathrm{AK}(P<$ 0.05 or $P<0.01)$. In addition, the SOC, $\mathrm{TN}, \mathrm{NH}_{4}^{+}-\mathrm{N}$, $\mathrm{NO}_{3}^{-}-\mathrm{N}, \mathrm{AP}$, and $\mathrm{AK}$ contents of soil were significantly positively correlated with each other $(P<0.05$ or $P<$ 0.01 ), and the soil capacity, total porosity, and capillary porosity were also significantly positively correlated with each other $(P<0.05$ or $P<0.01)$. These results indicated that the water permeability and water storage capacity of the soil significantly increased with increasing soil organic matter and available nutrients.

\section{Soil particle-size distribution for the three plantation stands}

The percentages of clay and silt in the topsoil of the three plantation stands were higher than those in the deep soil, which was gradually decreasing from topsoil to subsoil (Table 3). The different soil layers of $L$. principis-rupprechtii and $P$. crassifolia plantations had similar soil particle size composition. The sand content of subsoil was generally higher than topsoil, and the clay content of topsoil was generally higher than the subsoil. Moreover, the distribution of sand and clay contents of different soil layers had higher heterogeneity for the Pinus tabuliformis plantation stand.

\section{The relationship between soil particle-size distribution and soil physical and chemical properties}

Path analysis showed that soil organic carbon (SOC) had direct effects on clay (0.76), silt (0.66), and sand (-0.94), while total potassium (TK) had indirect effects on clay (0.75), silt (0.85), sand (-0.79). The SOC and TK had negative effects on sand, while SOC and TK had positive effects on clay and silt (Fig. 6). In addition, we can also find that SOC had a positive effect on TN, while SOC had a negative

Table 3 Characteristics of the various soil particle-size distribution (PSD) in the three soil profiles layers of different forest types

\begin{tabular}{|c|c|c|c|c|c|c|c|c|}
\hline \multirow[t]{2}{*}{ Tree species } & \multirow[t]{2}{*}{ Soil depth } & \multirow{2}{*}{$\begin{array}{l}\text { Clay }(\%) \\
<2 \mu \mathrm{m}\end{array}$} & \multicolumn{2}{|l|}{ Silt (\%) } & \multicolumn{4}{|l|}{ Sand (\%) } \\
\hline & & & $2.00-20.00 \mu \mathrm{m}$ & $20.00-50.00 \mu \mathrm{m}$ & $50.00-100.00 \mu \mathrm{m}$ & $100.00-250.00 \mu \mathrm{m}$ & $250.00-500.00 \mu \mathrm{m}$ & $500-2000 \mu \mathrm{m}$ \\
\hline \multirow[t]{3}{*}{ Larix principis-rupprechtii } & $0-10 \mathrm{~cm}$ & $8.66 \pm 0.38 a$ & $48.75 \pm 0.71 a$ & $27.21 \pm 0.35 a$ & $9.24 \pm 0.51 b$ & $4.46 \pm 0.53 b$ & $3.38 \pm 0.45 b$ & $0.18 \pm 0.09 c$ \\
\hline & $10-20 \mathrm{~cm}$ & $8.13 \pm 0.35 a$ & $43.67 \pm 0.96 a$ & $25.70 \pm 0.26 b$ & $10.06 \pm 0.10 b$ & $6.65 \pm 0.44 b$ & $6.41 \pm 0.46 a$ & $1.86 \pm 0.22 b$ \\
\hline & $20-30 \mathrm{~cm}$ & $5.96 \pm 0.50 \mathrm{~b}$ & $31.92 \pm 4.49 b$ & $22.99 \pm 0.34 c$ & $13.90 \pm 1.21 a$ & $10.65 \pm 1.44 a$ & $7.10 \pm 0.46 a$ & $3.06 \pm 0.55 a$ \\
\hline \multirow[t]{3}{*}{ Picea crassifolia } & $0-10 \mathrm{~cm}$ & $9.23 \pm 0.17 a$ & $51.35 \pm 0.79 a$ & $29.63 \pm 0.49 a$ & $8.61 \pm 0.41 b$ & $1.40 \pm 0.23 b$ & $3.79 \pm 0.63 c$ & - \\
\hline & $10-20 \mathrm{~cm}$ & $8.03 \pm 0.32 a$ & $46.45 \pm 2.23 a$ & $26.93 \pm 0.56 a$ & $8.43 \pm 0.34 b$ & $3.70 \pm 1.11 a b$ & $6.51 \pm 0.38 b$ & - \\
\hline & $20-30 \mathrm{~cm}$ & $6.31 \pm 0.58 b$ & $32.72 \pm 3.49 b$ & $18.23 \pm 3.84 b$ & $11.75 \pm 0.61 a$ & $5.83 \pm 0.77 a$ & $10.30 \pm 0.74 a$ & - \\
\hline \multirow[t]{3}{*}{ Pinus tabuliformis } & $0-10 \mathrm{~cm}$ & $8.88 \pm 0.29 a$ & $47.07 \pm 0.45 c$ & $18.62 \pm 2.00 b$ & $8.37 \pm 0.96 a$ & $1.03 \pm 0.32 \mathrm{a}$ & $20.63 \pm 1.41 a$ & - \\
\hline & $10-20 \mathrm{~cm}$ & $7.78 \pm 0.64 a b$ & $53.15 \pm 1.07 b$ & $24.99 \pm 0.42 a$ & $5.95 \pm 0.58 b$ & $2.11 \pm 0.26 b$ & $5.89 \pm 0.89 b$ & - \\
\hline & $20-30 \mathrm{~cm}$ & $6.46 \pm 0.54 b$ & $59.03 \pm 1.82 \mathrm{a}$ & $27.66 \pm 1.68 \mathrm{a}$ & $4.12 \pm 0.63 b$ & $7.37 \pm 2.31 c$ & $3.02 \pm 0.59 b$ & - \\
\hline
\end{tabular}

The different lowercase letters refer to significant differences among different soil layers in the same plantation stands $(P<0.05)$ 
effect on soil bulk density (BD). This also confirmed the results in Table 2.

\section{Discussion}

The interaction between leaves, litter, and soil nutrient contents for three different plantations

The plant-soil feedbacks as drivers of plant community composition and species coexistence are increasingly being recognized (Kulmatiski et al. 2008; Aponte et al. 2013; Kardol et al. 2013). Previous studies have shown that the $\mathrm{C}, \mathrm{N}$, and $\mathrm{P}$ contents of plants will significantly affect soil nutrient contents, and they are often speciesspecific in different species which have different nutrient contents and deliver different elemental contributions to soil (Vesterdal et al. 2008). As a result, the C:N:P stoichiometry of the soil will inevitably occur due to different litter inputs and rhizodeposition (Wang et al. 2009; Peichl et al. 2012; Zhang et al. 2019b), which is very important to improve our understanding of the relationship between plants and soil nutrient contents (Cleveland and Liptzin 2007; Zhao et al. 2015). In this study, we found that the C:N, C:P and N:P of leaves and litter of $P$. tabuliformis were higher than those of $L$. principis- rupprechtii and $P$. crassifolia. The possible reason for these results is that the $\mathrm{C}: \mathrm{N}$ and the nutrient contents of the litter are the most directly factors influencing decomposition rate and nutrient release of litters (Prescott 2010; Ge et al. 2013), and higher C:N and C:P are important in hindering the decomposition of litter. Conversely, the decrease in C:N and C:P means that litter is converted into a decomposed state more readily ( $\mathrm{He}$ et al. 2010). Moreover, the C:N and C:P of litter are negatively correlated with decomposition rate, and the litter with higher $\mathrm{C}: \mathrm{N}$ and $\mathrm{C}: \mathrm{P}$ needs to obtain a large amount of $\mathrm{N}$ and $\mathrm{P}$ from external sources to accelerate decomposition (Wang and Huang 2001; He et al. 2010). In addition, because $P$. tabuliformis litter is richer in lignin than $L$. principis-rupprechtii and P. crassifolia, decomposition is hampered (He et al. 2010). This conclusion is also confirmed by previous studies indicating that the lignin/ $\mathrm{N}$ or crude fiber/ $\mathrm{N}$ reflects the ease of litter decomposition: decomposition rate is negatively correlated with this ratio (Wang and Huang 2001; He et al. 2010). These reasons also explain why the soil nutrient contents of the $P$. tabuliformis plantation are lower than those of the L. principis-rupprechtii and $P$. crassifolia plantations.

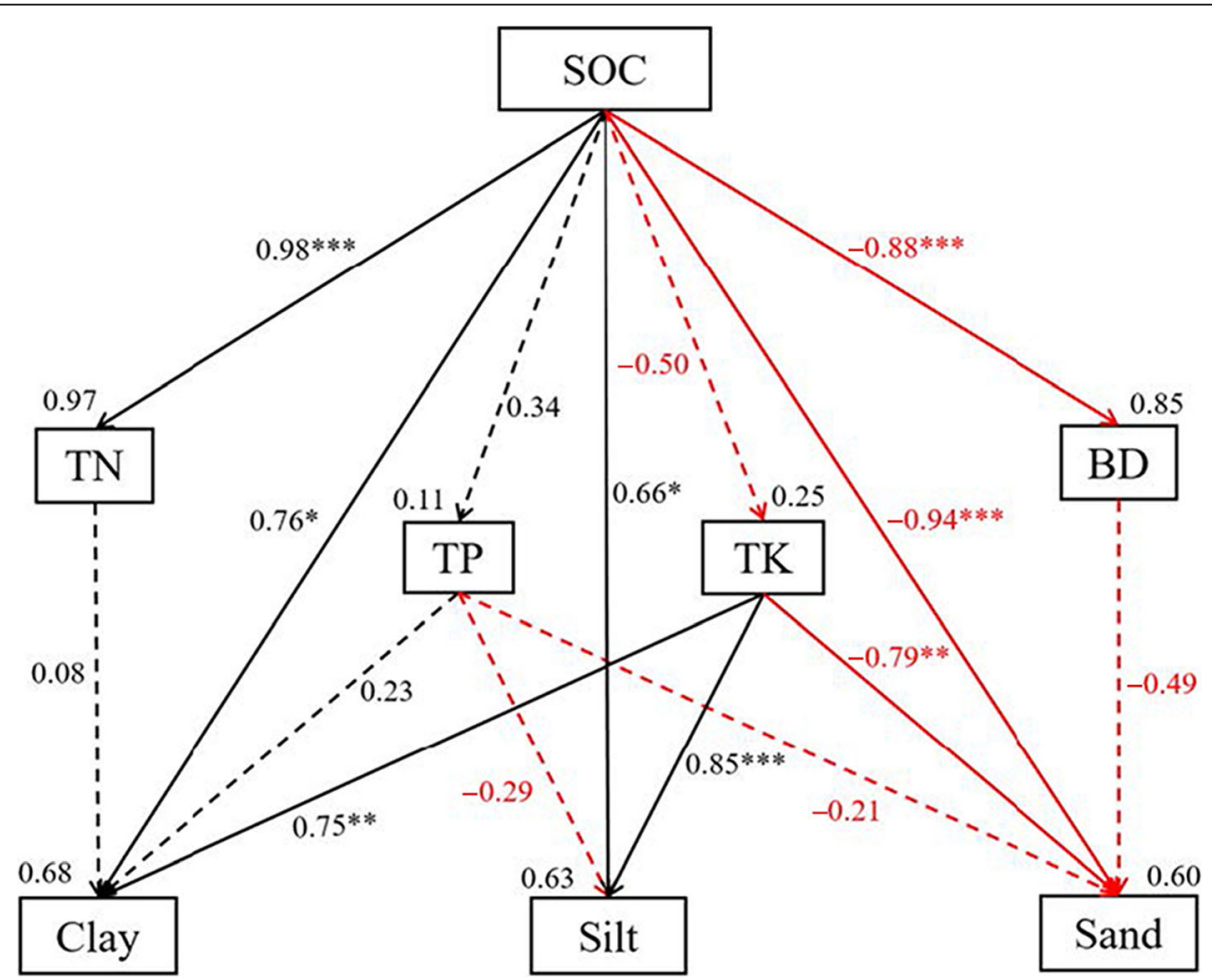

Fig. 6 Path diagram for the relationship between soil particle-size distribution and soil physical and chemical properties. Red solid lines indicate standardized regression weights are positive paths, black solid lines indicate standardized regression weights negative paths $\left({ }^{* * *}: P<0.001,{ }^{* *}: P<\right.$ $\left.0.01, *: P<0.05, x^{2} / \mathrm{df}=3.07\right)$, and dashed lines indicate standardized regression weights are not significant $(P>0.05)$. The numbers in the top-right corner of each box are the squared multiple correlations, and the numbers on the lines among these parameters are the standardized regression weights 
Soil C:N, C:P, and N:P are important indexes for determining the mineralization and fixation of soil nutrients during soil development (Tian et al. 2010). The N:P of soil not only reflect the availability of $\mathrm{P}$ and $\mathrm{N}$ in the forest ecosystem but also reveal nutrient movements between the plants and soils (Fan et al. 2015; Cao and Chen 2017). Our research results showed that the soil nutrient contents of the three plantations gradually decreased from the topsoil to deep soil layers. This trend was because that $\mathrm{C}, \mathrm{N}$ and $\mathrm{P}$ released by litter decomposition were mainly concentrated in the topsoil layer, with only a small percentage of nutrients reaching the deeper soil layers. Besides, the L. principis-rupprechtii stand had the highest soil $\mathrm{C}: \mathrm{N}, \mathrm{C}: \mathrm{P}$, and $\mathrm{N}: \mathrm{P}$, the $\mathrm{C}: \mathrm{N}$ and $\mathrm{C}: \mathrm{P}$ in leaves of $\mathrm{P}$. tabuliformis were higher than those of the other two species. Therefore, it can be speculated that the $P$. tabuliformis forest requires a larger amount of phosphorus than L. principis-rupprechtii and $P$. crassifoliastands, resulting in a decrease in phosphorus content in the soil. These also confirm the idea that the higher $\mathrm{C}: \mathrm{N}$ and $\mathrm{C}: \mathrm{P}$ values in plants usually represent higher $\mathrm{N}$ and $\mathrm{P}$ utilization (Wardle et al. 2004).

\section{Effects of three different plantations on soil nutrients}

It is well known that the soil is critical to maintaining the productivity and sustainability of forest ecosystems, and the ability of forest soil to store and transform organic material is influenced by the soil organic matter, which can be influenced by forest vegetation types (Liu et al. 2018; Xia et al. 2019). Therefore, knowledge about the soil nutrients in different forest soils is of great importance to understanding biogeochemical cycles (Yang et al. 2010). The results of this study showed that the SOC, TN, and available nutrients $\left(\mathrm{NH}_{4}^{+}-\mathrm{N}, \mathrm{NO}_{3}^{-}-\mathrm{N}, \mathrm{AP}\right.$, and $\mathrm{AK}$ ) were highest in the $L$. principis-rupprechtii stand, followed by the $P$. crassifolia stand, and lowest in the $P$. tabuliformis stand. Moreover, all nutrient contents declined with depth in the soil profile layer in the three different stands. This is because L. principis-rupprechtii is a deciduous coniferous species, so the biomass of litter input is higher than that of P. crassifolia or P. tabuliformis. In addition, the soil organic carbon accumulation may be mainly driven by litter inputs (Zhao et al. 2017), higher C:N and C:P hinder the decomposition of the litter layer (He et al. 2010). This suggests that the SOC, $\mathrm{TN}$, and available nutrient contents in the L. principisrupprechtii stands are higher than in the $P$. crassifolia and $P$. tabuliformis stands. Besides, the amount of potassium in the soil is directly related to the parent material (Mishra et al. 2017). Potassium in plants is involved in many important biochemical processes, such as activation of biological enzymes, ion channels, synthesis of macromolecules, and regulation of transpiration, etc.
(Mishra et al. 2017), and the availability of potassium in the soil is maintained by the decomposition of organic matter (Basumatary and Bordoloi 1992). This is the reason that there is no significant difference in TK, although there was a significant difference in AK content between different soil layers in the three stands.

The relationship between soil nutrient contents and soil physical properties for three different plantations

The water storage capacity of the soil is influenced by soil physical and chemical properties (Guzman et al. 2019). Soil bulk density and soil capacity play an important role in hydrological processes, which are essential to the supply and storage of water, nutrients, and oxygen in the soil (Wang et al. 2010; Krainovica et al. 2020). The size of soil porosity plays a key role in quantifying soil structure because it can affect soil hydraulic conductivity, solute convection and water retention (Zhang et al. 2019a). Therefore, these indicators can be used to evaluate the impact of vegetation restoration on soil properties ( $\mathrm{Gu}$ et al. 2018). The results of this study indicated that the SOC, TN, soil available nutrients and soil capacity, soil total porosity, and soil capillary porosity exhibited the same changing trends for different plantation species, and the correlation analysis (Table 2) also showed that the SOC, TN and available nutrient contents $\left(\mathrm{NH}_{4}^{+}-\mathrm{N}, \mathrm{NO}_{3}^{-}-\mathrm{N}, \mathrm{AP}\right.$, and $\left.\mathrm{AK}\right)$ were positively correlated with soil capacity, soil total porosity, and soil capillary porosity, while negatively correlated with soil bulk density. Furthermore, soil bulk density increased with the soil depth, and the differences in soil bulk density between the different species stands were mainly related to the degree of decomposition and amounts of easily decomposable litters. Our results are in agreement with previous studies showing that increases in SOC are associated with an increase in soil total porosity (Abu 2013) and decreases in soil bulk density (Koestel et al. 2013). Besides, there was also a significant positive correlation between $\mathrm{SOC}$ and available nutrients $\left(\mathrm{NH}_{4}^{+}-\mathrm{N}\right.$, $\mathrm{NO}_{3}^{-}-\mathrm{N}, \mathrm{AP}$, and $\mathrm{AK}$ ) (Table 2). These results indicate that the soil physical characters and water conservation capacity are largely affected by soil nutrient contents after afforestation.

\section{The relationship between soil particle-size distribution and soil physical and chemical properties of three different plantations}

In general, the vegetation can not only improve soil fertility, increase carbon storage, enhance water conservation capacity, etc., but also improve soil particle composition, reduce the content of sand and silt, increase the content of clay, and thus improve soil structure (Su et al. 2018; Xia et al. 2020). The results of this 
study indicated that $L$. principis-rupprechtii and P. crassifolia plantations could significantly improve the nutrient contents of topsoil, make the topsoil particles finer, increase the clay content and decrease the sand content, compared with $P$. tabuliformis plantation. The main reason is that $L$. principis-rupprechtii and $P$. crassifolia plantations had higher soil nutrient returning capacity than P. tabuliformis plantations, which further increased the soil nutrient contents, improved the soil structure, and promoted the formation of soil clay. The soil particle-size distribution is closely related to soil organic carbon content and has a significant influence on soil organic carbon conversion (von Lützow and Kögel-Knabner 2009). Generally, soil organic carbon is easy to combine with finer soil particles (silt and clay) to form organic-inorganic complexes. Meanwhile, the surface area is relatively large of silt and clay, which will expose more positive charges and combine with negatively charged humus (Zhao et al. 2014). On the other hand, the finer particles have poor permeability, and the organic carbon is more difficult to be decomposed by microorganisms once it combines with them. Compared with finer clay, sand particles are opposite to each other. Because sand has fewer positive charge sites and larger particles, they have fewer opportunities to combine with organic carbon. Moreover, sand has strong permeability, looser soil structure and poorer soil water holding capacity, which can be easily decomposed by microorganisms (Zhao et al. 2014; Xia et al. 2020). Therefore, this is also the reason why the clay has a negative effect on soil bulk density.

\section{Conclusions}

In this study, we investigated the influence of different tree species on the nutrient cycling of plants and soils and plant-soil feedbacks, as well as the interaction between soil physicochemical properties in semi-arid mountain forest ecosystems. Our study suggests that $L$. principis-rupprechtii and P. crassifolia had higher TN, TP, and TK contents in their leaves and litter layers than P. tabuliformis, while P. tabuliformis had higher organic carbon, C:N and C:P in leaves and litter than $L$. principis-rupprechtii and P. crassifolia. This suggests that higher C:N and C:P hinder the decomposition of litter. Thus, the leaves and litter layers strongly influence soil nutrient availability through their biogeochemical processes, $L$. principis-rupprechtii and $P$. crassifolia plantation forests had a more substantial improvement in soil nutrients and clay component than $P$. tabuliformis plantation forest. In addition, the L. principis-rupprechtii and $P$. crassifolia significantly improved the clay component, soil capacity, soil total porosity, and capillary porosity, decreased soil bulk density and sand component associated with a larger void ratio, and enhanced water storage capacity. In conclusion, we recommend planting $L$. principis-rupprechtii and P. crassifolia as the preferred tree species to enhance the water conservation function and increase soil fertility, which should be useful for ecological vegetation construction and management in semi-arid mountain forest ecosystems.

\section{Acknowledgements}

The authors thank the personnel at the Gansu Xinglongshan National Nature Reserve and Gansu provincial field scientific observation and research station of mountain ecosystems for providing assistance.

\section{Authors' contributions}

Changming Zhao and Chun Han conceived and designed the experiments. Cankun Zhang, Yongjing Liu, and Yage Li performed the experiments. Chun Han and Yage Li analyzed the data, Chun Han wrote the manuscript. All authors provided editorial advice and gave final approval for publication.

\section{Funding}

This work was supported by the Strategic Priority Research Program of the Chinese Academy of Sciences (XDA20100101), a Major Special Science and Technology Project of Gansu Province (18ZD2FA009) and the National Natural Science Foundation of China (NSFC) (31522013).

\section{Availability of data and materials}

The datasets used and/or analysed during the current study are available from the corresponding author on reasonable request.

Ethics approval and consent to participate

Not applicable.

Consent for publication

Not applicable.

\section{Competing interests}

The authors declare that they have no competing interests.

Received: 6 August 2020 Accepted: 11 January 2021

Published online: 21 January 2021

References

Abu ST (2013) Evaluating long-term impact of land use on selected soil physical quality indicators. Soil Res 51:471-476. doi:https://doi.org/10.1071/SR12360

Aponte C, García LV, Marañón T (2013) Tree species effects on nutrient cycling and soil biota: a feedback mechanism favouring species coexistence. Forest Ecol Manag 309:36-46. doi:https://doi.org/10.1016/j.foreco.2013.05.035

Ayres E, Steltzer H, Berg S, Wallenstein MD, Simmons BL, Wall DH (2009) Tree species traits influence soil physical, chemical, and biological properties in high elevation forests. PLoS One 4(6):e5964. doi:https://doi.org/10.1371/ journal.pone.0005964

Bao SD (2000) Soil and agriculture chemistry analysis. China Agriculture Press, Beijing (in Chinese)

Basumatary A, Bordoloi PK (1992) Forms of potassium in some soils of Assam in relation to soil properties. J Ind Soci Soil Sci 40(3):443-446

Cao Y, Chen YM (2017) Ecosystem C:N:P stoichiometry and carbon storage in plantations and a secondary forest on the Loess Plateau, China. Ecol Eng 105: 125-132. doi:https://doi.org/10.1016/j.ecoleng.2017.04.024

Chang RY, Fu BJ, Liu GH, Yao XL, Wang S (2012) Effects of soil physicochemical properties and stand age on fine root biomass and vertical distribution of plantation forests in the Loess Plateau of China. Ecol Res 27(4):827-836. doi: https://doi.org/10.1007/s11284-012-0958-0

Clemente AS, Werner C, Máguas C, Cabral MS, Martins-Louçao MA, Correoa O (2004) Restoration of a limestone quarry: effect of soil amendments on the establishment of native Mediterranean sclerophyllous shrubs. Restor Ecol 12: 20-28. doi:https://doi.org/10.1111/j.1061-2971.2004.00256.x

Cleveland CC, Liptzin D (2007) C:N:P stoichiometry in soil: is there a "Redfield ratio" for the microbial biomass? Biogeochemistry 85:235-252. doi:https://doi. org/10.1007/s10533-007-9132-0

Fan HB, Wu JP, Liu WF, Yuan YH, Hu L, Cai QK (2015) Linkages of plant and soil C: $\mathrm{N}: \mathrm{P}$ stoichiometry and their relationships to forest growth in subtropical 
plantations. Plant Soil 392:127-138. doi:https://doi.org/10.1007/s11104-0152444-2

Fu XL, Shao MA, Wei XR, Horton R (2010) Soil organic carbon and total nitrogen as affected by vegetation types in Northern Loess Plateau of China. Geoderma 155:31-35. doi:https://doi.org/10.1016/j.geoderma.2009.11.020

Ge X, Zeng LX, Xiao WF, Huang ZL, Geng XS, Tan BW (2013) Effect of litter substrate quality and soil nutrients on forest litter decomposition: a review. Acta Ecol Sin 33(2):102-108. doi:https://doi.org/10.1016/j.chnaes.2013.01.006

Gu CJ, Mu XM, Gao P, Zhao GJ, Sun WY, Tatarko J, Tan XJ (2018) Influence of vegetation restoration on soil physical properties in the Loess Plateau, China. J Soil Sediment 19(2):716-728. https://doi.org/10.1007/s11368-018-2083-3

Guzman JG, Ussiri DAN, Lal R (2019) Soil physical properties following conversion of a reclaimed minesoil to bioenergy crop production. Catena 176:289-295. doi:https://doi.org/10.1016/j.catena.2019.01.020

He F, Wang DX, Lei RD, Wang J, Wang YC, Liu JH (2010) Decomposition characteristics of withered leaves at different altitudes on south slope of the Qinling Mountains. Acta Botanica Boreali-Occidentalia Sinica 30(5):1004-1011. doi:https://doi.org/10.3724/SP.J.1231.2010.06705

Hobbie SE, Reich PB, Oleksyn J, Ogdahl M, Zytkowiak R, Hale C, Karolewski P (2006) Tree species effects on decomposition and forest floor dynamics in a common garden. Ecology 87(9):2288-2297. doi:https://doi.org/10.1890/00129658(2006)87[2288:tseoda]2.0.co;2

Hu HC, Tian FQ, Hu HP (2011) Soil particle size distribution and its relationship with soil water and salt under mulched drip irrigation in Xinjiang of China. Sci China Technol Sci 54(6):1568-1574. doi:https://doi.org/10.1007/s11431-010-4276-x

Huang ZQ, Wan XH, He ZM, Yu ZP, Wang MH, Hu ZH, Yang YS (2013) Soil microbial biomass, community composition and soil nitrogen cycling in relation to tree species in subtropical China. Soil Biol Biochem 62:68-75. doi: https://doi.org/10.1016/j.soilbio.2013.03.008

Jean-Francois B, Yelena F, Claude G, Danilo M, Marcelo R, Devin R, Constantin MZ, Thomas WC (2019) The global tree restoration potential. Science 365(6448):76-79. doi:https://doi.org/10.1126/science.aax0848

Kardol P, Bezemer TM, van der Putten WH (2006) Temporal variation in plant-soil feedback controls succession. Ecol Lett 9(9):1080-1088. doi:https://doi.org/10. 1111/j.1461-0248.2006.00953.x

Kardol P, de Deyn GB, Laliberté E, Mariotte P, Hawkes CV (2013) Biotic plant-soil feedbacks across temporal scales. J Ecol 101:309-315. doi:https://doi.org/10. $1111 / 1365-2745.12046$

Koestel JK, Norgaard T, Luong NM, Vendelboe AL, Moldrup P, Jarvis NJ, Lamandé M, Iversen BV, de Jonge LW (2013) Links between soil properties and steadystate solute transport through cultivated topsoil at the field scale. Water Resour Res 49:790-807. doi:https://doi.org/10.1002/wrcr.20079

Kou M, Garcia-Fayos P, Hu S, Jiao JY (2016) The effect of Robinia pseudoacacia afforestation on soil and vegetation properties in the Loess Plateau (China): a chronosequence approach. Forest Ecol Manag 375:146-158. doi:https://doi. org/10.1016/j.foreco.2016.05.025

Kozlowski TT (2002) Physiological ecology of natural regeneration of harvested and disturbed forest stands: implications for forest management. Forest Ecol Manag 158(1):195-221. doi:https://doi.org/10.1016/s0378-1127(00)00712-x

Krainovica PM, Bastos RP, de Almeida DR, Juniord AFN, Sampaio PTB, de Souzaa LAG, Falcão NPS (2020) Effect of rosewood plantation chronosequence on soil attributes in Central Amazonia. Geoderma 357:1 13952. doi:https://doi. org/10.1016/j.geoderma.2019.113952

Kulmatiski A, Beard KH, Stevens JR, Cobbold SM (2008) Plant-soil feedbacks: a meta-analytical review. Ecol Lett 11:980-992. doi:https://doi.org/10.1111/j. 1461-0248.2008.01209.x

Liu S, Yang M, Cheng F, Coxixo A, Wu X, Zhang Y (2018) Factors driving the relationships between vegetation and soil properties in the Yellow River Delta, China. Catena 165:279-285. doi:https://doi.org/10.1016/j.catena.2018.02.004

Lucas-Borja ME, de Santiago JH, Yang Y, Shen Y, Candel-Pérez D (2018) Nutrient, metal contents and microbiological properties of litter and soil along a tree age gradient in Mediterranean forest ecosystems. Sci Total Environ 650:749758. doi:https://doi.org/10.1016/j.scitotenv.2018.09.079

Mishra G, Das PK, Borah R, Dutta A (2017) Investigation of phytosociological parameters and physico-chemical properties of soil in tropical semievergreen forests of Eastern Himalaya. J For Res 28(3):513-520. doi:https:// doi.org/10.1007/s11676-016-0330-2

Mohammadi MH, Meskini-Vishikaee F (2013) Predicting soil moisture characteristic curves from continuous particle-size distribution data. Pedosphere 23(1):70-80. doi:https://doi.org/10.1016/S1002$0160(12) 60081-2$
Norris M, Avis P, Reich P, Hobbie S (2012) Positive feedbacks between decomposition and soil nitrogen availability along fertility gradients. Plant Soil 367:347-361. doi:https://doi.org/10.1007/s11104-012-1449-3

Peichl M, Leava NA, Kiely G (2012) Above- and belowground ecosystem biomass, carbon and nitrogen allocation in recently afforested grassland and adjacent intensively managed grassland. Plant Soil 350:281-296. doi:https://doi.org/10. 1007/s11104-011-0905-9

Prescott CE (2010) Litter decomposition: what controls it and how can we alter it to sequester more carbon in forest soils? Biogeochemistry 101:133-149. doi: https://doi.org/10.1007/s10533-010-9439-0

Prescott CE, Grayston SJ (2013) Tree species influence on microbial communities in litter and soil: current knowledge and research needs. Forest Ecol Manag 309(4):19-27. doi:https://doi.org/10.1016/j.foreco.2013.02.034

Qi F, Zhang RH, Liu X, Niu Y, Zhang HD, Li H, Li JZ, Wang BY, Zhang GG (2018) Soil particle size distribution characteristics of different land-use types in the Funiu mountainous region. Soil Till Res 184:45-51. doi:https://doi.org/10. 1016/j.still.2018.06.011

Qiao LL, Li YZ, Song YH, Zhai JY, Wu Y, Chen WJ, Liu GB, Xue S (2019) Effects of vegetation restoration on the distribution of nutrients, glomalin-related soil protein, and enzyme activity in soil aggregates on the Loess Plateau, China. Forests 10(9):796. doi:https://doi.org/10.3390/ f10090796

Qiu XC, Peng DL, Wang HB, Wang ZY, Cheng S (2019) Minimum data set for evaluation of stand density effects on soil quality in Larix principis-rupprechtii plantations in North China. Ecol Indic 103:236-247. doi:https://doi.org/10. 1016/j.ecolind.2019.04.010

Su M, Ding GD, Gao GL, Zhang Y, Guo MS (2018) Multi-fractal analysis of soil particle size distribution of Pinus sylvestris var. mongolica plantations in Hulunbeier sandy land. J Arid Land Resour Environ 32(11):129-135. doi: https://doi.org/10.13448/j.cnki.jalre.2018.345

Sun C, Liu G, Xue S (2016) Natural succession of grassland on the Loess Plateau of China affects multifractal characteristics of soil particle-size distribution and soil nutrients. Ecol Res 31(6):891-902. doi:https://doi.org/10.1007/s11284016-1399-y

Tian HQ, Chen GS, Zhang C, Melillo JM, Hall CAS (2010) Pattern and variation of C:N:P ratios in China's soils: a synthesis of observational data. Biogeochemistry 98:139-151. doi:https://doi.org/10.1007/s10533-009-9382-0

van der Putten WH, Bardgett RD, Bever JD, Bezemer TM, Casper BB, Fukami T, Kardol P, Klironomos JN, Kulmatiski A, Schweitzer JA, Suding KN, van de Voorde TFJ, Wardle DA (2013) Plant-soil feedbacks: the past, the present and future challenges. J Ecol 101(2):265-276. doi:https://doi.org/10.1111/13652745.12054

Vesterdal L, Schmidt IK, Callesen I, Nilsson LO, Gundersen P (2008) Carbon and nitrogen in forest floor and mineral soil under six common European tree species. Forest Ecol Manag 255(1):35-48

von Lützow M, Kögel-Knabner I (2009) Temperature sensitivity of soil organic matter decomposition-what do we know? Biol Fert Soils 46(1):1-15. doi: https://doi.org/10.1007/s00374-009-0413-8

Wang J, Huang JH (2001) Comparison of major nutrient release patterns in leaf litter decomposition in warm temperate zone of China. Acta Phytoecological Sinica 25(3):375-380

Wang GL, Liu GB, Xu MX (2009) Above- and belowground dynamics of plant community succession following abandonment of farmland on the Loess Plateau, China. Plant Soil 316:227-239. doi:https://doi.org/10.1007/s11104008-9773-3

Wang Y, Shao M, Shao H (2010) A preliminary investigation of the dynamic characteristics of dried soil layers on the Loess Plateau of China. J Hydrol 381: 9-17. doi:https://doi.org/10.1016/j.jhydrol.2009.09.042

Wardle DA, Walker LR, Bardgett RD (2004) Ecosystem properties and forest decline in contrasting long-term chronosequences. Science 305(5683):509513. doi:https://doi.org/10.1126/science.1098778

Xia JB, Ren JY, Zhang SY, Wang YH, Fang Y (2019) Forest and grass composite patterns improve the soil quality in the coastal saline-alkali land of the Yellow River Delta, China. Geoderma 349:25-35. doi:https://doi.org/10.1016/j. geoderma.2019.04.032

Xia JB, Ren RR, Chen YP, Sun J, Zhao XM, Zhang SY (2020) Multifractal characteristics of soil particle distribution under different vegetation types in the Yellow River Delta Chenier of China. Geoderma 368:114311. doi:https:// doi.org/10.1016/j.geoderma.2020.114311

Xiang N, Peng G, Bing W, Yu L (2015) Fractal characteristics of soil retention curve and particle size distribution with different vegetation types in 
mountain areas of northern China. Int J Environ Res Public Health 12(12): 15379-15389. doi:https://doi.org/10.3390/ijerph121214978

Xu GC, Li ZB, Li P (2013) Fractal features of soil particle-size distribution and total soil nitrogen distribution in a typical watershed in the source area of the middle Dan River, China. Catena 101:17-23. doi:https://doi.org/10.1016/j. catena.2012.09.013

Yang YH, Fang JY, Guo DL, Ji CJ, Ma WH (2010) Vertical patterns of soil carbon, nitrogen and carbon: nitrogen stoichiometry in Tibetan grasslands. Biogeo Discuss 7:1-24. doi:https://doi.org/10.1590/50104-11692010000600002

Yang XD, Ni K, Shi YZ, Yi XY, Zhang QF, Fang L, Ma LF, Ruan JY (2018) Effects of long-term nitrogen application on soil acidification and solution chemistry of a tea plantation in China. Agric Ecosyst Environ 252:74-82. doi:https://doi. org/10.1016/j.agee.2017.10.004

Zhai JY, Song YH, Entemake W, Xu HW, Wu Y, Qu Q, Xue S (2020) Change in soil particle size distribution and erodibility with latitude and vegetation restoration chronosequence on the Loess Plateau, China. Int J Environ Res Public Health 17:822. doi:https://doi.org/10.3390/ijerph17030822

Zhang GS, Liu YF (2018) The distribution of microplastics in soil aggregate fractions in southwestern China. Sci Total Environ 642:12-20. doi:https://doi. org/10.1016/j.scitotenv.2018.06.004

Zhang C, Xue S, Liu GB, Song ZL (2011) A comparison of soil qualities of different revegetation types in the Loess Plateau, China. Plant Soil 347:163-178. doi: https://doi.org/10.1007/s11104-011-0836-5

Zhang GS, Zhang FX, Li XT (2019a) Effects of polyester microfibers on soil physical properties: perception from a field and a pot experiment. Sci Total Environ 670:1-7. doi:https://doi.org/10.1016/j.scitotenv.2019.03.149

Zhang W, Liu WC, Xu MP, Deng J, Han XH, Yang GH, Feng YZ, Ren GX (2019b) Response of forest growth to C:N:P stoichiometry in plants and soils during Robinia pseudoacacia afforestation on the Loess Plateau, China. Geoderma 337:280-289. doi:https://doi.org/10.1016/j.geoderma.2018.09.042

Zhao XM, Zhao LP, Guo XX, Li MT, Yu SS, Wang MY (2014) Particle component and distribution characteristics of organic carbon of sediments in water and shore soils. J Soil Water Conserv 28(6):304-308. doi:https://doi.org/10.13870/j. cnki.stbcxb.2014.06.056

Zhao FZ, Kang D, Han XH, Yang GH, Yang GH, Feng YZ, Ren GX (2015) Soil stoichiometry and carbon storage in long-term afforestation soil affected by understory vegetation diversity. Ecol Eng 74:415-422. doi:https://doi.org/10. 1016/j.ecoleng.2014.11.010

Zhao FZ, Zhang L, Sun J, Ren CJ, Han XH, Yang GH, Pang GW, Bai HY, Wang Y (2017) Effect of soil C, N and P stoichiometry on soil organic c fractions after afforestation. Pedosphere 27(4):705-713. doi:https://doi.org/10.1016/S10020160(17)60479-X

Zhou XN, Zhou Y, Zhou CJ, Wu ZL, Zheng LF, Hu XS, Chen HX, Gan JB (2015) Effects of cutting intensity on soil physical and chemical properties in a mixed natural forest in southeastern China. Forests 6(12):4495-4509. doi: https://doi.org/10.3390/f6124383

\section{Submit your manuscript to a SpringerOpen ${ }^{\circ}$ journal and benefit from:}

- Convenient online submission

- Rigorous peer review

- Open access: articles freely available online

- High visibility within the field

- Retaining the copyright to your article

Submit your next manuscript at $\boldsymbol{\nabla}$ springeropen.com 